\title{
LIETUVOS AVIACINIŲ INSTITUCIJŲ ISTORINĖ APŽVALGA 1919-1940 M.
}

\author{
Vyr. Itn. Valius Urbonas \\ Kariniu oro pajègu Aviacijos bazès Sraigtasparnių eskadrile
}

\begin{abstract}
Anotacija. Straipsnyje nagrinejama Lietuvos aviacija 1919-1940 metais. Autorius naudodamasis jam prieinamais istoriniais ir literatūriniais šaltiniais siekia išanalizuoti tarpukario aviacinių žinybu bendradarbiavima, atlikti istorinę aviaciniu institucijų analizę.

Apžvelgus istorinị šiu institucijų vystymasi galime daryti išvada, kad nuo pat aviacinių instituciju kūrimosi pradžios pagrindinis tikslas buvo šalies gynyba ginkluoto užpuolimo atveju. Aviacijos branduoliu tapo karine aviacija.
\end{abstract}

Pagrindiniai žodžiai: Lietuvos kariuomenè, tarpukario aviacija, Lietuvos aeroklubas.

İvadas. Nuo pat senųjų laikų visi dideli laimèjimai ir ịvairių sričių pasiekimai buvo paremti bendradarbiavimo politika ir bendrų veiksmų derinimo sėkme. Visi didieji karybos, mokslo ir visuomeniniai laimèjimai buvo pasiekti remiantis kitu patirtimi ir koordinuojant tarpusavio veiksmus.

Po Pirmojo pasaulinio karo, kuriantis Lietuvos kariuomenei, neatsiejama kariuomenès dalimi tapo Lietuvos kariuomenès aviacija. „1919 m. sausio $30 \mathrm{~d}$. Lietuvos kariuomenejje suformuojama Inžinerijos kuopa, vadovaujama karininko Juozo Narako. Kuopoje buvo ir aviatorių būrys. Atkūrus Nepriklausomą Lietuvos valstybę imta kurti Karines oro pajègas. (Algimantas Liekis, „Science and Arts of Lithuania“. „Lietuvos mokslas“, „Lietuvos karo aviacija“ (1919-1940), p. 86-139)

$1927 \mathrm{~m}$. balandžio $28 \mathrm{~d}$. ịkurtas Lietuvos aeroklubas (LAK), kuris nuo pat ịkūrimo pradžios labai glaudžiai ir noriai bendradarbiavo su Karine aviacija gynybos klausimais ir rengiant bendras varžybas ar lakūnus. LAK ịkūrèjais laikomi Karinès aviacijos atstovai. Ypač glaudus bendradarbiavimas ir koordinuotas veiksmų derinimas šalies gynybos politikoje užpuolimo ar karo atveju. Taip pat labai geras bendradarbiavimo pavyzdys tuometeje dar jaunoje Lietuvos valstybeje buvo nauja aviacijos šaka - Šaulių sajungos aviacija. Tai patriotinè organizacija, kuri buvo ikurta prie 6-osios priešlèktuvinès apsaugos šaulių kuopos. Tuometejje Lietuvoje ikurta sklandymo sekcija. Šaulių aviacija glaudžiai bendradarbiavo su Karine aviacija ir LAK. Šaulių sajungos paskirtis buvo ruošti parašiutininkus ir lavinti atsargos lakūnus.

Straipsnis pradedamas tarpukario Lietuvos aviacinių institucijų bendradar- 
biavimo analize - apžvelgiama tarpukario Lietuvos aviacinių padalinių svarba šalies gynybos politikai minètu laikotarpiu. Nagrinejjamas aviacinių institucijų ir su aviacija susijusių ịstaigų (Šaulių sąungos, LAK) veikla ir pagalba Valstybės saugumui ir gynybai. Atkūrus kariuomenès funkcijas imta kurti ir plèsti turimus aviacinius pajègumus ir aviacijos pramonę.

Straipsnyje nagrinejjama pirminè aviacinių institucijų (kaip atskirų vienetų) bendradarbiavimo tvarka. Trumpai apžvelgiama Lietuvos aviacinių institucijų raida ir institucijų bendradarbiavimas nuo 1919 m. sausio 30 d., kai buvo ịkurta Aviacijos dalis. Glaustai aptariama Aviacijos svarba ir aptariamos tuometès aviacinès institucijos, lyginamos institucijų funkcijos ir atsakomybès rajonai.

Tyrimo objektas - tarpukario Lietuvos aviacinių institucijų tarpžinybinis bendradarbiavimas.

Tyrimo tikslas - apžvelgti tarpukario Lietuvos aviacines institucijas ir jų bendradarbiavimą.

\section{Tyrimo uždaviniai:}

Aptarti tarpukario Lietuvos aviacinius pajègumus.

Apžvelgti aviacinių institucijų istorinę raidą.

Išsiaiškinti, kokiu būdu ir kokiu tikslu bendradarbiavo Lietuvos aviacinès žinybos.

Tyrimo metodai: karo aviacijos istorinès literatūros apžvalgos ir retrospektyvinis metodai.

\section{Lietuvos tarpukario aviacijos istorinė apžvalga}

Prieš pradedant analizuoti Lietuvos Respublikos (toliau - LR) aviacijos raidą ir vystymąsi pagal atliekamų funkcijų pobūdị turime paminèti, kad aviacija kaip atskira transporto rūšis ir kaip naujas dalykas pradètas realizuoti jau nuo senų senovès. „Leonardo da Vinčio projektai, F. Verančio parašiutas, F. Lanos orlaivis, Dž. Borelio paukštis. Iš šių žmonių projektų matome, kad noras skraidyti, palengvinti ir išplèsti žmogaus galimybes buvo jau nuo seno. Susidomèjimas erdvès užkariavimu buvo ir yra žmogaus svajone tik keičiasi viešpatavimo sferos bei ribos“ (Liekis A., Lietuvos mokslas: Lietuvos karo aviacija. Vilnius, 1999, p. 9). Oro erdvès užkariavimas tapo galimas, kai broliai Mongolfjè ir R. Chodasevičius parodè pasauliui oro balionų galybę ir pastūmėjo aviacijos vystymąsi. Šiais savo išradimais padèdami pamatus kitų instruktorių kūrybai. „Lietuvoje Kazimieras Semenavičius aprašo daugiapakopes raketas ir parengia knygą „Didysis artilerijos menas“. Pirmasis oro baliono skridimas Lietuvoje pademonstruotas $1809 \mathrm{~m}$., kuri pademonstravo J. Kuparentka“ (Liekis A., Lietuvos mokslas: Lietuvos karo aviacija. Vilnius, 1999, p. 39). Tai įrodo, kad ir LR neliko nuošalyje aviacijai gimstant ir tobulejjant.

Pirmojo lèktuvo projekto „Žemaičio garlekys“ Lietuvoje autorystė priklauso A. Griškevičiui. Dar labai įdomus dalykas, kad Steponas Vilkaitis (lietuvis) piloto pažymėjimą gavo iš paties Orvilio Raito (Orwille Wright). Juozas Kraucevičius - 
pirmasis lietuvių kilmès lakūnas tapęs kvalifikuotu pilotu, mokslus baigęs carinèje Rusijoje ir 1919 metais pradèjęs vadovauti atkurtoms Lietuvos karinèms oro pajègoms. Galime teigti, jog nuo pat valstybès gyvavimo pradžios oro pajègų vairas buvo patikimose patyrusio žmogaus rankose. Lietuvos karininkai J. Dobkevičius ir A. Gustaitis prie Lietuvos aviacijos kūrimo prisidejo ne vien nepriekaištinga tarnyba, bet ir lietuviškų orlaivių kūrimu. Šiuos lietuvius galime laikyti tautos didvyriais, nes jie pasauliui įrodè, kad Lietuva pati gali kurti ir plètoti aviaciją

1919 m. Europoje pradèta plètoti komercinè ir keleivinè aviacija, nes be darbo buvo likę daug karo lakūnų ir to reikalavo technologijų raida. Lietuvoje buvo dar tik pats karinių konfliktų ịkarštis, o Europa jau turejo minčių apie komercinès aviacijos kūrimą, kuriai pamatus padejjo būtent karinè aviacija. Taigi ịvyko aviacijos skilimas ir tam tikrų funkcijų pasidalijimas. Ir iš to galime spręsti, kad bendradarbiavimas ir bendri interesai yra labai svarbūs ir neatsiejami dalykai. Lietuvoje 1921 m. karinè aviacija pradejjo gabenti karinị paštą i ịvairias Lietuvos vietas. Galime daryti išvadą, kad aviacijos funkcijos pradèjo plèsti savo ribas ir galime ịžvelgti bendradarbiavimą vykdant ne tik karinius veiksmus, bet ir taikos meto užduotis. 1922 m. atidarytas maršrutas Karaliaučius-Maskva (nusileidimas Kaune). Taigi matyti, kad ir būdama jauna, atkurtoji Lietuvos valstybe neliko nuošalyje ir netgi glaudžiai bendradarbiavo su užsienio valstybėmis civilinès aviacijos klausimais. J. Dobkevičiui sukūrus pirmajị savos konstrukcijos orlaivị buvo remtasi pasauline spauda apie aviacijos tobulèjimą ir kitais pasaulio aviacijos atradimais ir laimėjimais. Atidžiai nagrinėdami to meto lakūnų užrašus ir dokumentus galime teigti, kad tarp valstybių (tarp jų ir Lietuvos) vyko nuoseklus bendradarbiavimas: perkant variklius, atskirus mazgus ar dalis, kurių Lietuvos pramonè negamino. „Aviacijos dirbtuvès be ịprastinių remontų pradejjo gaminti lèktuvus, kopijuodamos turimas vokiškas konstrukcijas. Buvo panaudojami įsigyti vokiški aviaciniai varikliai ir kitos lèktuvų dalys ir prietaisai, o gaminami sparnai, liemenys, uodegos plokštumos“ (Ašmenskas V., Lietuvos aeroklubas 1927-1940 metais. Vilnius 2007, p. 30).

Pirmasis apie Civilinès aviacijos kūrimo būtinybę prakalbo S. Darius. Jis žinojo, kaip yra Amerikoje, o apie užsienio šalyse veikiančius aeroklubus, juos vienijančią Tarptautinę aeronautikos federaciją, skatinančią sportinès aviacijos veiklą, Lietuvoje buvo kalbejjęs ne tik jis. Šiai S. Dariaus minčiai pritarè ir kiti to meto lakūnai: A. Gustaitis, J. Narakas ir kiti. Aeroklubo reikejo populiarinant aviaciją, pritraukiant ir sudominant žmones. Karinė aviacija to daryti negalejjo, ją varžè kariné drausmé, subordinacija ir slaptumas. Matome, kad tada buvo sumanyta tarpusavyje bendradarbiauti, tačiau dèl minètos priežasties pasidalytos funkcijos ir veiklos sferos. Tačiau matome, kad vis vien viską jungia aviacija.

1927 m. ịkūrus LAK nustatytos ir klubo funkcijos ir uždaviniai. LAK tikslas buvo ruošti ịvairių sričių aviacijos specialistus ir tobulinti jų parengimą, puoselèti oro sportą, sudominti visuomenę oreivyste. Tikslas, rodantis Lietuvos aviacinių institucijų bendradarbiavimą gynybos klausimais, - supažindinti visuomenę su savisauga per oro antpuolius ir parengti klubo narius šalies gynybai. Tai rodo, kad šalies 
gynybos politika nebuvo užmiršta ir kuriant civilinę aviaciją.

LAK buvo pavesta rengti ir tobulinti civilinès ir transporto aviacijos lakūnus, rūpintis pašto perskraidinimu ir organizuoti keleivinį transportą. Galime teigti, jog svarbus dalykas jau tada buvo aviacinių institucijų funkcijų pasiskirstymas ir kuo glaudesnis bendradarbiavimas, siekiant kaip įmanoma geresnių rezultatų. LAK garbės pirmininkas A. Smetona pabrèžè: „Kuo stipresnè kurios tautos aviacija, tuo pranašesnè tauta“. Bendradarbiaujant KOP ir LAK buvo parengti priešlèktuvinès apsaugos įstatymai, suformuota Oro susiekimo inspekcija, ịkurtos oro susiekimo linijos Kaunas-Palanga. Tai rodo, kad šios aviacinès struktūros glaudžiai bendradarbiavo nustatant šių institucijų funkcijas ir veiklos sritis. LAK nuo pat ịkūrimo pradejo aktyviai bendradarbiauti su užsienio šalių klubais ir tarptautinėmis organizacijomis aviaciniais klausimais. $1935 \mathrm{~m}$. per LAK visuotinį susirinkimą buvo nuspręsta, kad lakūnai, kurie buvo ruošiami civilinei aviacijai, karo atveju būtu tinkami atlikti karo lakūnų funkcijas. Šiuo klausimu LAK vadovybė glaudžiai bendradarbiavo su Karine aviacija. Turime pabrèžti ir tai, kad LAK ịkūrejjai ir didžioji klubo narių dalis buvo sudaryta iš Lietuvos karininkų. Todèl bendradarbiavimas tapo dar glaudesnis ir veiksmingesnis. Karo aviacija LAK aprūpindavo lèktuvais ir rengè lakūnus.

1936 m. ịkurtas Šaulių aviacijos būrys, kurio įkūrimą paskatino LAK prezidentas. Pagrindinis Šaulių aviacijos būrio tikslas buvo labiau rūpintis oro susisiekimu, rengiant parašiutininkus, ir lavinti atsargos lakūnus, kad neprarastų igūužių. Karo metu buvo nustatyti ir kiti tikslai: vykdyti žvalgybos ir ryšių užduotis. Tai rodo stiprius ryšius tarp visų trijų aviacinių institucijų tarpukario Lietuvoje. Visų struktūrų uždaviniai ir tikslai siejo valstybès gynybos politiką ir lakūnų rengimą. Galime pastebėti glaudaus bendradarbiavimo požymius, kurie turejjo nulemti aviacijos raidos spartą ir tobulèjimą Lietuvoje. Dar vienas glaudaus Šaulių sajungos ir LAK bendradarbiavimo pavyzdys yra tai, jog Šaulių sajunga naudojo LAK lèktuvų angarus ir visą LAK aviacini turtą. Dar neturime pamiršti ir oro skautų būrelio, kuris buvo įkurtas $1939 \mathrm{~m}$. prieš pat sovietų okupaciją. Tačiau oro skautų susitikimas ịvyko tik kartą, kurio metu keli jaunuoliai buvo apmokyti sklandyti ir išlaikè egzaminus. Oro skautų būrelis buvo kuriamas Šaulių sajungos pagrindu, skautų būrelis turejo tapti Šaulių sajungos šaka, mokančia jaunimą sklandyti ir taip pritraukti $\mathfrak{i}$ aviaciją. Pagrindinis tikslas ir buvo bendradarbiavimas su karinėmis pajègomis šalies gynybos atveju. Taikos metu oro skautų veikla turejo populiarinti aviaciją ir puoselèti jos tradicijas. $1918 \mathrm{~m}$. İsteigus Susisiekimo ministeriją jai buvo pavesta vadovauti Geležinkeliams, Laivynui, Civilinei aviacijai, Sausumos kelių transportui, Paštui ir telefonui. Tad ministerijai buvo nurodyta pavesti visoms minètoms institucijoms jų gaires ir veiklos sritis. Pasaulyje civilinès aviacijos reikšmė itin padidejo po Pirmojo pasaulinio karo ir išplèsta karo aviacija labai greitai buvo pritaikyta civilinèms reikmėms. Europos valstybèse civilinės aviacijos reikalais rūpinosi civilinès aviacijos ministerijos, o Lietuvoje civilinès aviacijos klausimus buvo pavesta kuruoti Susisiekimo ministerijai, kuri rūpinosi ne civiline aviacija, o paštu, 
telefonu ir telegrafu, nes atskiros institucijos kaip Civilinès aviacijos ministerija iki 1936 m. nebuvo. Visais aviaciniais klausimais rūpinosi ir juos koordinavo karinè aviacija. $1919 \mathrm{~m}$. siekiant sureguliuoti oro susisiekimą tarptautiniu mastu buvo pasirašyta Tarptautinė konvencija, kurios pagrindinis principas buvo kiekvienos šalies oro erdvės suverenumo pripažinimas. Tačiau Lietuva šios konvencijos nepasirašè ir prie jos neprisijungè. Galime teigti, jog Lietuva dar nebuvo pasirengusi tarptautiniu mastu bendradarbiauti su kitomis Europos valstybemis civilinès aviacijos klausimais. Matyti, kad Lietuva tuo metu ị civilinę aviaciją nedejo daug vilčių, nors vèliau be to nebuvo įmanoma išsiversti. Taip pat trūko ir tarptautinio bendradarbiavimo patirties. Reikia nepamiršti, kad buvo per anksti jaunai valstybei greitai viską kurti sunkmečiu. $1921 \mathrm{~m}$. civilinès aviacijos veiklą administravo Paštų, telegrafų ir telefonų valdyba, kuri vèliau reorganizuota. $1934 \mathrm{~m}$. valdyboje atsiradus aviacijos referento etatui buvo pradèta formuoti ir civilinè aviacija, kuri turëjo tapti atskira institucija. Šiuo klausimu tarpusavyje glaudžiai bendradarbiavo Karinès oro pajègos ir Susisiekimo ministerija. Matyti, kad naujų aviacinių institucijų kūimui Lietuvoje didelę įtaką turèjo jau esamos aviacijos pajègos. 1936 m. prie Susisiekimo ministerijos ịsteigta Orinio susisiekimo inspekcija, kuri tapo dabartinès Civilinès aviacijos Lietuvoje motina. $1940 \mathrm{~m}$. Orinio susisiekimo inspekcija turèjo būti reorganizuota ị Orinio susisiekimo direkciją. Galime ižžvelgti, jog ties Civilinès aviacijos klausimu dirbta daug ir daug pastangų jai atsirasti dèjo kitos aviacinès tarnybos, esančios Lietuvoje. Visus klausimus, kuriuos sprendè Lietuvos aviacinès institucijos ir kaip jos tarpusavyje bendradarbiavo matome iš pasiektų rezultatų. Orinio susisiekimo inspekcijos pradinis tikslas buvo prižiūrèti aviaciją: tikrinti lakūnų kvalifikaciją, stebėti orlaivių tinkamumą skraidyti, organizuoti ir reglamentuoti tinkamą orlaivių ženklinimą ir prižiūrèti aerodromus. Tai nebuvo atskira aviacijos šaka, turinti savo orlaivių parką, savo struktūrą ir lakūnus. Jai buvo pavesta kontroliuoti Karines oro pajègas, Šaulių aviaciją. Orinio susiekimo ministerijai buvo pavesta bendradarbiauti su Lietuvos aviacinemis institucijomis aviaciniais klausimais. Tačiau 1936 m. ịkūrus Orinio susisiekimo direkciją Civilinè aviacija pradejo savo veiklą. Pirmuoju direkcijos inspektoriumi paskirtas J. Špokevičius, kuris buvo karininkas ir glaudžiai bendradarbiavo su Karinėmis oro pajègomis dèl naujų naikintuvų pirkimo Didžiojoje Britanijoje ir Čekoslovakijoje. Tarpukario metais Orinio susisiekimo valdyba bendradarbiavo su Šaulių sajungos aviacija, Orinio sporto sajunga. Išskaidžius aviacines institucijas ị civilines ir karines atsiranda funkcijų ir veiklos sferų pasiskirstymas. Pradedama bendradarbiauti įvairiose srityse, tiek įsigyjant orlaivius, tiek apmokant personalą ir ji licencijuojant. Orinio susisiekimo inspekcija rūpinosi tarptautinio susisiekimo per Lietuvą tvarkymu ir reguliavimu. Tokiu būdu bendradarbiavo su užsienio valstybèmis ir šalies viduje esančiomis aviacinèmis institucijomis. Tarptautinių linijų lèktuvai nereguliariai nusileisdavo Lietuvoje, ne dèl to, kad būtų buvę prasti ryšiai, o dèl prastos aerodromų būklès ir netinkamos aerodromų infrastruktūros. Tik $1930 \mathrm{~m}$. Krašto apsaugos ministerijai bendradarbiaujant su Susisiekimo ministerija praplèstas Kauno aerodromas. Taip pat Kaunas tapo 
tarptautinių oro susiekimo linijų mazgu. Dar labiau Orinio susisiekimo inspekcijos veikla sustiprèjo, kai vis platesnę veiklą ėmè vystyti LAK. Sukūrus šias institucijas jų veikla itin sustiprèjo ir išsiplète tarpžinybinio bendradarbiavimo ryšiai. Visos Lietuvos aviacine veikla užsiimančios institucijos glaudžiai ir noriai bendradarbiavo tarpusavyje, nes jas vienijo bendri interesai ir panašios veiklos sritys. Susisiekimo aviacija daug naudojosi Kauno karo aviacijos aerodromu. Šioms institucijoms kartu bendradarbiaujant aerodromas buvo padalytas ị dvi dalis. Šiaurinè aerodromo dalis buvo skirta Susisiekimo aviacijai, paskirtas šalia esantis angaras ir pastatyta $1 \mathrm{~kW}$ galingumo radijo stotis. Kariškiai rūpinosi aerodromo apsauga, kartu saugodami ir Susisiekimo aviacijos aerodromo dalį, angarą ir teritoriją, priklausančią Civilinei aviacijai. Ryškejja bendradarbiavimo ne tik aviaciniais klausimais stiprejjimas, bet ir infrastruktūros apsaugos ir pasidalijimo srityje. Netgi ateityje planuojant naujų civilinių aerodromų statybą buvo numatoma jų paskirtis karinèms reikmėms. „Kadangi tie aerodromai bus viešai naudojami ir bus, be abejo, naudingi karo aviacijai“ (Algimantas L. Lietuvos mokslas. Vilnius 1999, p. 370). Kompleksinị aviacijos plètojimą valstybejje rèmė Karo aviacijos viršininkas A. Gustaitis, skatindamas aviamodelizmą, sklandymą, parašiutizmą, sportinę susisiekimo aviaciją. Jis teigè, kad tai yra tos pačios aviacijos sudètinès dalys, galinčios tarnauti šalies pažangai ir valstybės gynimo reikalams. Tai rodo, kad aviacijos tarnybos buvo susietos glaudžiais ryšiais, nes bendravo tarpusavyje ịvairiais klausimais, svarbiausias jų yra šalies suverenumo išsaugojimas, institucijų veiklos plètimas, užduočių ir veiklos sferų pasiskirstymas. A. Gustaitis teigè, kad institucijų bendradarbiavimas turi būti kuo glaustesnis, kad esant reikalui šalies gynybos atveju būtų pakankamai paruoštų specialistų užduotims atlikti. „Juo daugiau jaunuolių bus uždegta entuziazmu, juo geresni aviacijos personalą galima bus pasirinkti ir panaudoti gynybai, juo bus aukštesnè mūsų aviacijos ginklo kokybë“ (Liekis A. Lietuvos mokslas. Vilnius, 1999, p. 372).

1938 m. Lietuvos Susisiekimo ministerija iš Anglijos užsakẻ du keleivinius lèktuvus „Percival“. Tačiau jie buvo be Pito vamzdelių (Orlaivių padèties erdvejje nustatymo priemonè) šildymo. Tai sukeldavo nesklandumų skraidant maršrutais i kitas valstybes, tad ir vèl buvo prašoma kariuomenès pagalbos. Karinės oro pajėgos i prašymą atsakè teigiamai. „Turiu garbès paprašyti ir Tamsta generole, jei būtų galima, sutikti paskolinti Ministerijai 2 šildomus Pito vamzdelius, keturias odines striukes su kailiukais ir 4 poras šiltų batų, iki ministerija įsigys nuosavų“ (Liekis A., Lietuvos mokslas. Vilnius, 1999, p. 375). Apžvelgę galime teigti, kad buvo bendradarbiaujama ne tik aviacinių dalių skolinimosi ar perdavimo klausimais, tačiau vyko ir tarpžinybinis bendradarbiavimas. $1939 \mathrm{~m}$. įkūrus Orinio sporto sajungą, jai kuruoti paskirtas karininkas dèl to, kad būtų kuo glaudesnis ir atsakingesnis institucijų bendradarbiavimas. Orinio sporto sajunga su Karo aviacija palaikė glaudžius ryšius ir vèliau turèjo didelių užmojų, kad Orinio sporto sajunga imtų vadovauti LAK, Šaulių aviacijai ir kitoms organizacijoms. Iš to galime daryti išvadą, kad gausèjant aviacinių struktūrų skaičiui Lietuvoje buvo stengiamasi jas jungti ị vieną 
sistemą ir nustatyti jų veiklos sritis. Pagrindinè visų organizacijų funkcija buvo ginti Lietuvos valstybę karo atveju.

\section{Išvados}

Apibendrinant galima teigti, kad tarpukario Lietuvos aviacija buvo gan stipri ir nenusileido kitoms Europos valstybėms savo išsivystymo lygiu. Karinè aviacija ir jos aerodromai tapo pagrindu kitoms Lietuvos aviacijos žinyboms, Lietuvos aeroklubui, Šaulių aviacijai, Civilinei aviacijai ir oro skautams.

Daugelis lietuvių lèktuvų savo techninėmis, taktinėmis savybėmis prilygo garsiausiems atitinkamos klasès Europos lèktuvams. Lietuviai sklandytojai ir aviamodeliuotojai buvo minimi tarp geriausių pasaulyje.

Prezidentas A. Smetona yra pasakęs: „Kuo stipresnè kurios tautos aviacija, tuo pranašesnè tauta“.

Išanalizavus LR istorinị aviacinių institucijų bendradarbiavimą, galima daryti išvadą, kad iki sovietų okupacijos Lietuvos aviacinis išsivystymas buvo gan aukšto lygio. Visų to meto LR aviacinių institucijų bendras tikslas buvo šalies gynyba ginkluoto užpuolimo atveju. Matyti, kad šalyje esančių aviacinių tarnybų (Šaulių sajungos, Oro skautų būrelio, Civilinès aviacijos, LAK) bendras tikslas valstybės oro erdvės apsauga. Nors ir šių institucijų veiklos sritys buvo skirtingos.

Apibendrinus galima teigti, kad visos Lietuvos tarpukario aviacijos šakos ir žinybos siekè vieno bendro tikslo - ginti šali ginkluoto užpuolimo atveju.

\section{Šaltiniai ir literatūra}

1. Ašmenskas, V. (2007). Lietuvos Aeroklubas 1927-1940 metais. Vilnius.

2. Aviacijos pasaulis. (2007). Vilnius.

3. Lietuvos kariuomenès Karinès oro pajègos. [žiūrèta: 2011.11.23]. Prieiga per internetą: http://lt.wikipedia.org/wiki/Lietuvos_kariuomen\%C4\%97s_ Karin\%C4\%97s_oro_paj\%C4\%97gos.

4. Lietuvos kariuomenès Karinès oro pajègos 1992-2003 m. [žiūrèta: 2011.11.25]. Prieiga per internetą: http://kariuomene.kam.lt/lt/kariuomenes_struktura/karines_oro_pajegos/istorija_1854/lietuvos_kariuomenes_karines_oro_ pajegos_1992_-2003_m.html.

5. Lietuvos kariuomenès kronika. [žiūrèta: 2011.11.23]. Prieiga per internetą: http://kariuomene.kam.lt/lt/kariuomenes_atributika/karo_istorija/kariuomenes_ kronika.html. 


\title{
HISTORICAL REVIEW OF THE LITHUANIAN AVIATION INSTITUTIONS IN THE PERIOD OF 1919-1940
}

\author{
1 st Lt Valius Urbonas \\ Lithuanian Air Force Air Base
}

\section{Summary}

Since the ancient times, all big successes and achievements in various fields have been based on cooperation policy and joint coordination success. All great military, scientific and social successes have been achieved on the basis of the experience of others and coordination of their actions.

The article deals with the interwar Lithuanian aviation in the period of 1919-1940. By using all available historical and literature resources, the author aims to analyze the cooperation of the interwar aviation department and perform historical analysis of aviation authorities.

The Lithuanian Armed Forces have started developing after the World War I with military aviation as an integral part. Led by Juozas Narako, the Engineering Company was established on 30 January 1919. It also included an aviation squad. When an independent state of Lithuania was restored, the military air force has started developing (Algimantas Liekis Science and Arts of Lithuania, Science of Lithuania, War Aviation of Lithuania (1919-1940), p. 86-139).

In case of an attack or war, a close cooperation and coordinated plan of actions were addressed in the country's defence policies. Another example of cooperation in the young state of Lithuania was a new branch of aviation, i.e. a riflemen aviation unit. This patriotic organization was founded under the 6th Anti-aircraft Protection Riflemen Company. At that time, a gliding section was founded as well. The purpose of the Riflemen's Union was to train parachutists and reserve pilots.

The article deals with the initial stage of cooperation among aviation authorities (as separate units). It is a brief overview of the development of the Lithuanian aviation institutions and their cooperation since 30 January 1919 when military aviation came into existence.

Having reviewed the historical development of these institutions, it can be concluded that since their foundation the main purpose has been the country's defence in case of an armed attack. Military aviation has become the core of aviation. 


\section{AUTORIAUS LYDRAŠTIS}

Autoriaus vardas, pavardè: Valius Urbonas

Mokslo laipsnis ir vardas: -

Darbo vieta ir pareigos: Lietuvos kariuomenès Karinių oro pajėgų Aviacijos bazès Oro operacijų grupès Sraigtasparnių eskadrilès C grandies lakūnas

Autoriaus mokslinių interesų sritys: Karo aviacijos istorija, partizaninis judejjimas

Telefonas ir el. pašto adresas: 860600 012; valius.urbonas10@gmail.com

\section{AUTHOR'S COVER LETTER}

Author's name and surname: Valius Urbonas

Academic degree and name:

Workplace and position: Lithuanian Air Force Air Base, Air Operation Group, Helicopter Squadron, Pilot

Author's research interests: air force history, partisan movement

Telephone and e-mail address: +370 60600 012; valius.urbonas10@gmail.com 